\title{
Paradoxical Figure And Application In Carita Pantun Sunda
}

\author{
Aris Darisman \\ Visual Communication Design Department \\ Sekolah Tinggi Teknologi Kreatif Bina Nusantara Bandung \\ Email:adarisman@binus.edu
}

\begin{abstract}
Characterization is a reconstruction of form and meaning as a manifestation of Sundanese cultural identity. Characterization is reflected in story narratives with prose and poetic expressions. Paradoxical figures and characterizations in the carita pantun format give a character description that is manifested in imaginary figures. Characterization is the first step in reconstructing characters. The figure or character is an entity of Sundanese community value in which it manifests in the belief (religion), social, cultural and historical context sublimated to Carita Pantun. Pantun is not only a symbol but a sacred symbol. Generaly there's no different between Carita pantun and the myths that exist in other countries. Carita pantun is a mythology. This study uses a qualitative method of paradoxical aesthetic approach through descriptive interpretive to provide an in-depth description and interpretation of the subject. The analysis model includes characterization analysis and paradoxical aesthetic analysis through narrative symbols on Carita pantun.
\end{abstract}

Keyword: characterization, paradoxical aesthetics, carita pantun

\section{INTRODUCTION}

Carita Pantun is a cultural symbol, mind of the Sundanese people. Pantun is not only a symbol but also a sacred symbol. Pantun is an old sunda religious system which formulates the concepts of the order of existence ${ }^{1}$. Human existence with nature greatly influences the mindset of the Sundanese community. Sundanese pantun is the result of Sundanese culture in the mythical-spiritual era which is closely related to the mindset and order of primordial life. Carita Pantun is not only a performing art, but also a guide which contains philosophy, values, history, geography and socio-culture. The expression of love and gratitude is the main foundation of his cosmology. Love and gratitude to the Creator, fellow human beings and nature.

Basically Carita pantun is a mythology. Unlike other regional mythologies, Indonesian mythology generally tells how the universe is formed, how humans are formed, how humans and nature relatations, how humans relate to God. The mythology of the Sundanese rhyme contains Sundanese cultures and symbols referring to cultural concepts. Reading symbols in pantun can bring the readers or audiences to the cultural

\footnotetext{
${ }^{1}$ (Sumardjo, 2009: 50)
} 
pattern of Sundanese society in his era. It can be concluded that Sundanese society is a very symbolic ${ }^{2}$ society, a symbol of the transcendent world.

Generaly there's no different between Carita pantun and the myths that exist in other countries. The stories are about the heroic stories of the characters in defending the weak, stories of struggle that must be faced with various obstacles and challenges, the depiction of an ideal country or kingdom where its people live in prosperity with fertile land, a battle between good against evil, justice against anger. Although carita pantun actually has values that are more profound and sacred, and it does not carelessly bring it, it can be used to attract public interest. For the people of West Java, especially Sundanese, the characters in the pantun way are very familiar. The existence of these figures is always associated with real figures of the Kings in Tatar Sunda, for example Prabhu Siliwangi, Léngsér, Prabhu Mundinglaya Dikusumah, Ciung Wanara, Lutung Kasarung etc.

The figures of Carita pantun formed in a story but some people believe that they are real. The characters in the various stories are illustrated as paradoxical figures, it means that these characters have a God-human, good-bad, stupid-intelligent, innocentauthoritative character. For example, the Léngsér figure in the tradition of carita pantun sunda is a paradox, in some ways the pantun is described as a servant, a messenger but Léngsér is a teacher with intelligence and wisdom, nurturing kings and warriors, with the guidance of prospective kings and warriors to be tough, magic and wise in carrying out the teachings and running the State.

The Sundanese society has a speech culture so that the visualization of the characters is not clearly described and they are generally symbolic. In East Java, the artifacts are clearly visualized so that they make a big difference with Sundanese culture. It is certainly a challenge to visualize objects from the concept of "imaginary" cosmology to full visual of the character.

The description of characterization figure in the Sundanese Carita Pantun is very minimal considering that Sundanese society is a speech culture meaning that the visualization of the characters is not clearly described and it is generally symbolic. Being different from the East, the artifacts are clearly visualized.

In this study, the author will examine one stage of the characterization process, especially in imaginary figures of the Sundanese pantun carita. This is where the role of "local wisdom" objects, especially in designing characters or character design as a vehicle of knowledge, especially the development of culture to provide information and knowledge of noble values

\footnotetext{
${ }^{2}$ Symbols are objects, events, speech sounds or written forms that are given meaning by humans. The primary form of symbolization by humans is language. But humans also communicate by using signs and symbols in painting, dance, music, architecture, facial expressions, gestures, etc. (Saifuddin, 2005: 289).
} 


\section{RESEARCH METHODS}

This study uses a type of qualitative research. Qualitative research is a method for exploring and understanding meaning by a number of individuals or groups of people ascribed to social or humanitarian ${ }^{3}$ problems. This research is conducted with the Paradox Aesthetic approach, this is intended to identify, parse and analyze data or certain phenomena so that they can be understood. The research techniques are descriptive interpretive, meaning to provide an in-depth description and interpretation of character paradoxics and characterization of Carita Pantun.

\subsection{Paradoxical Aesthetics}

Paradoxical aesthetics reveals to Indonesian human thoughts \& activities, especially the context of collective thinking and the diversity of human pre-modem \& moderncultural arts. The concept of paradox arises when ancient Indonesian humans realized that everything and existence existed, consisted of opposite pairs, both opposition pairs and twin pairs. The pairs of each partner have value, both objective-empirical value, and subjective value of consciousness. There is no night, there is beautiful, there is bad, there is a man there is a woman, there is a face behind, there is heat there is cold, there is upstream there is downstream, and thousands of other couples.

The belief in mythology is the collective faith of tribal people. No matter whether the myths make sense and they are consistent with their human experience or not. Indeed, Indonesian myths reject the human empirical picture. The myth contains cosmic work, both micro, macro and meta, which are indeed full of surprising events. Mythical logic is spontaneity and it does not make common sense. The logic of myth is the logic of metacosmos, not microcosm logic. The logic of metacosmos is the logic of trust, the logic of faith. They believe that all mythical events are the truth. All mythical events are logical ${ }^{4}$.

The third pattern in Indonesian pre-modern culture developed in a primordial society that lived by farming. Why three paterns? This community lives on its own business, which is farming. Farmers live on land by creating (planting), maintaining and developing rice, as well as other side plants. His obsession is "turn on". Life is nurturing life. Life can continue to be preserved by marrying conflicting but complementary opposition twins. From marriage, new life arises and there will be above and below, heaven and earth, male and female. Marriage will both create a third entity, namely life on earth. The sky is above, the earth is below and life appears in the midst of heaven and earth.

The three worlds with the three societies are the one that makes this life exist. The third creature of the world is a unity and visiting each other. Humans can visit the underworld and the upper world, as well as the creatures of the upper world and the underworld can meet in the underworld, even marry one another. The basis of human cosmology is that this cultivator is the basis for mythical thinking, namely the three pattern. The third pattern departs from the antagonistic dualism of all things.

\footnotetext{
${ }^{3}$ John W. Creswell. Research Design. Qualitative, Quantitative and Mixed Approaches. Yogyakarta: Student Library. 2012 (p. ${ }^{4}$ )
${ }_{\text {Sumardjo, 2010:346) }}$
} 


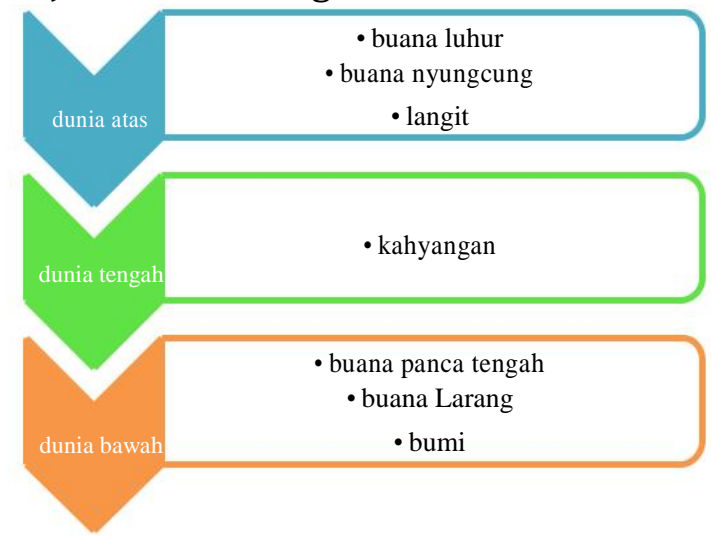

Figure 1. The Three Patterns of Paradox Aesthetics

(Source : Darisman, 2018)

\subsection{Figure Characterizations}

According to Pickering and Hoeper (1981, p.27) in Minderop, in presenting and determining the characters of the figures, generally the author uses two methods in his work. First is the direct method (telling) and second is the indirect method (showing). The telling method relies on the character's exposure to the exposition and direct comments from the author. The showing (indirect) method shows the author placing himself outside the narrative by giving an opportunity to the characters to display their character through dialogue and action.

The story character has a very important role in a story. The story figure brings a moral message that is deliberately presented to the reader. According to Abram in Nurgiyantoro (2012, p. 165), the character of the story (character) is the person (s) displayed in a narrative karaya or drama, which the reader interpreted as having certain moral qualities and tendencies as expressed in speech and what was done in action. According to Nurgiyantoro (2012, p. 176), there are several types of figures in a fiction that can be distinguished based on the angle at which the naming is done, such as : Main Figures and Additional Figures, Protagonist and Antagonist Figure, Simple and Round Figure, Static Figures and Developing Figures, and Typical Figures and Neutral Figures.

In terms of the role or level of importance of the characters in the story, there are figures who are dominant most of the stories (main characters) and conversely there are figures who only appear once or several times the story (additional figures).

Based on the appearance of a character, it can be distinguished into protagonists and antagonists. A protagonist is a character we admire - one of the popular types called hero - a character that embodies ideal norms, values for us (Altenbernd \& Lewis, 1966, p. 59).

Based on his statement, the character can be divided into a simple character or a flat character or a round or complex character. Simple characters in their original form are figures who have only one particular quality, one characteristic - certain character. 
Around figure is a character who has and revealed various possibilities on the side of his life, his personality and identity ${ }^{5}$.

Based on the criteria for developing, figures in a novel, characters can be distinguished into static figures and developing characters. According to Nurgiyantoro (2012, p.188) Static figures are characters who essentially do not experience changes and / or developments in rank as a result of events that occur. Developing figures are story characters who experience change and development of ranks in line with the development (and change) of events and plots narrated.

Based on the possibility of mirroring the character of the story can group humans from real life. The character of the story can be distinguished into a typical character and a neutral character. According to Nurgiyantoro (2012, p. 190-191) A typical figure is a character who only slightly shows the state of individuality. A neutral character is a story character who has existence for the sake of the story itself. He is truly an imaginary figure who only lives and exists in a fictional world. He presents (or presented) solely for the sake of the story or even he is actually the master of the story, the perpetrator of the story and told.

\subsection{RESULTS AND DISCUSSION}

In general, the characterization of this story is no different from other stories such as puppet stories where the characters consist of gods, humans (represented by Kings, Knights, folk), clowns and antagonists such as giants, other mystical creatures. The common thread between stories is also formed, there are times when the Gods descend into the world disguised as humans, giving teachings to the Kings, Knights or humans in general, also the ambitions of the antagonists to confront humans and gods. For example Semar character, Semar is one of the protagonists in the puppet world. He served the Pandawa, as a Punakawan, Semar is always asked by the Pandawa. He served as well as an "elder" for the Pandawa, protector and advisors. Actually the figure of Semar is a "god" means God, Semar is actually Sanghyang Ismaya, son of Sanghyang Tunggal and he is the brother of Batara Guru Kahyangan. Semar (Sanghyang Ismaya) is a representation of the upper world and the underworld, he became a paradox when he has to unite between the role of God and his humanitarian duties as a cleric / pawongan so he represented himself as an ordinary people.

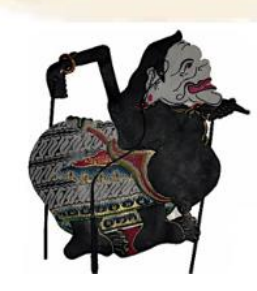

Figure 2 : Semar

Source : $\underline{\text { https://id.wikipedia.org/wiki/Semar }}$

\footnotetext{
${ }^{5}$ Burhan Nurgiyantoro. Teori Pengkajian Fiksi. 2012. Yogyakarta. Gadjah Mada University Press (hal 182-183
} 
Even in the context of pantun story, it is not different from puppet stories. The story illustrates the journey of kings, the knights who traveled on their quest for identity, saving the kingdom, searching for spouses and always being accompanied by pawongan. Sundanese pantun story currently has many variants of the story, namely the carita of East Priangan pantun (Bandung, Sumedang, Kuningan-Subang) and the western parts such as Banten-Bogor rhyme. The author takes several samples of the title of the pantun and below is a table of some of the verses of the pantun with the characters.

\begin{tabular}{|l|l|}
\hline \multicolumn{1}{|c|}{ Pantun Story } & \multicolumn{1}{c|}{ Characterizations } \\
\hline Mundinglaya Dikusuma, & $\begin{array}{l}\text { Prabhu Mundinglaya Dikusuma, Pohaci Wiru } \\
\text { Mananggay, Yaksa Mayuta }\end{array}$ \\
\hline Ciung Wanara, & Sang Permana Dikusumah, Ciung Wanara, Léngsér \\
\hline Lutung Kasarung, & \begin{tabular}{l} 
Lutung Kasarung, Léngsér \\
\hline Budak Manyor, \\
Budak Manyor (Raden Patih Sutra kalang \\
Panggung Aria Mangku Nagra), Sunan Ambu, \\
Léngsér
\end{tabular} \\
\hline Munding Kawati, & $\begin{array}{l}\text { Ratna Sari and Ratna Kembang, Yaksa Mayuta, } \\
\text { Prabhu Munding Kawati }\end{array}$ \\
\hline
\end{tabular}

Tabel.1 Pantun story and Characterization

(Source : Darisman, 2018)

From the several characterizations above, the author takes the example of a character based on an additional main character, protagonist-antagonist and static-developing figure, and represents the scope of gods, humans and other mystical beings.

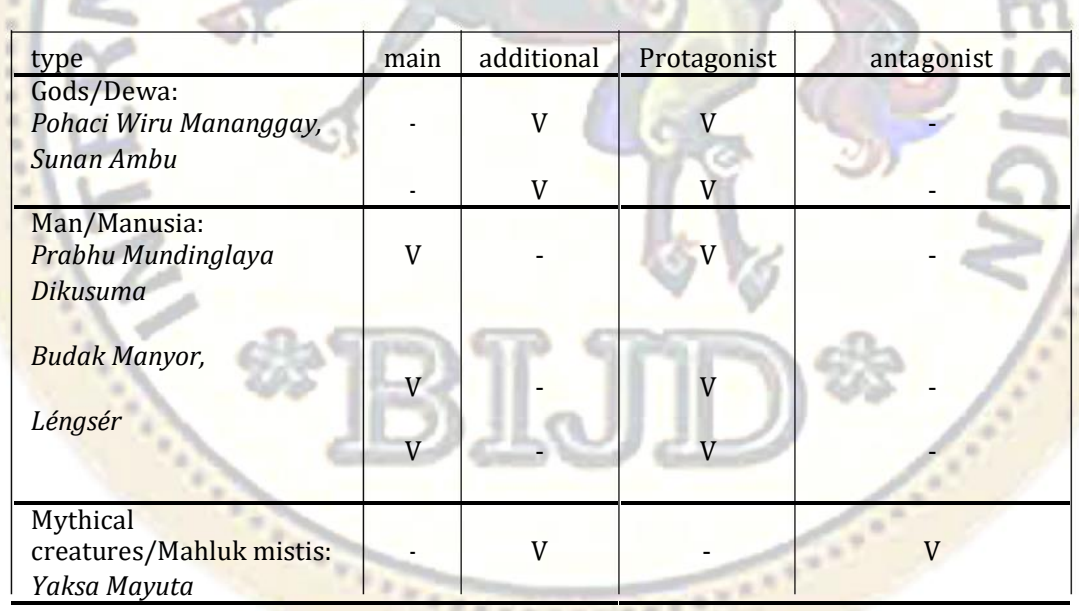

Tabel.2 Characterization and Role

(Source : Darisman, 2018)

Furthermore, to find out the characteristics of the characters, we can find out through 2 methods namely telling and showing by analyzing the dialogical narrative of the characters. Mundinglaya Dikusumah was ordered by Pohaci Wiru Mananggay to retrieve Langlayang Salaka Domas in Jabaning Langit. Pohaci Wiru Mananggay or in other stories identical to Sunan Ambu is an entity that represents the world above / buana nyungcung, he is a "God" represented by a woman. It is well known as women who are symbols of mother earth / motherland, meaning that the figure of Pohaci Wiru Mananggay is a symbolic paradox that she is in the middle of the middle / lower 
Balong International Journal of Design

world, but her existence is in the world above. The relation with its characteristics is the word of God, acting as a God, leader of the Hyang, Deity, Goddess in heaven; firm, dignified, motherly.

Prabhu Mundinglaya Dikusuma and Manyor Slave (the great Raden Patih Sutra of Aria Mangku Stage Nagra) are the main characters, protagonists and developing characters in the story. The equation of both is a son of the King and the Kingdom Knight. Both are underworld entities or buana tengah / buana Larang, both of them represent human entities with all their advantages and disadvantages. They became paradoxical when they met death, living in Buana Nyungcung and in heaven and being revived to complete their journey. The journey of a human figure in the Buana tengah/ Buana Barang headed to Buana Nyungcung and in heaven then returned to the world. It has relations with the characteristics of the King's words, leaders and kings of an empire in central Buana / Buana Larang; firm, dignified, populist.

Léngsér is an additional character, the protagonist and character develops in every way in the Sundanese pantun. The Léngsér figure presents in every story, he is a human figure with an advisory role, the King's assistant. Léngsér is a catalyst between the king and his people. Léngsér is an entity of Buana Panca Tengah / Buana Larang and the above world. His role is same as Semar as a Pawongan for the Kings and other people. That is the paradox of Léngsér. Relations with the characterization of the word Pandita, symbols of the people and the teacher for humans, authority, innocent, as is, firm, humorous.

Yaksa Mayuta is an additional character, antagonist and static figure. Yaksa Mayuta is an antagonistic creature in the form of a giant and this mythological creature is in almost every carun with different characters and names. Yaksa Mayuta represents obstacles, barriers, passions, and more symbolizes the human ego. Yaksa Mayuta is a paradox, he is a creature of heaven who comes from the top of the world / buana nyungcung and lives in the Buana Tengah. The relation of characterization of ego / lust is an angry symbol of anger, authority, firm.

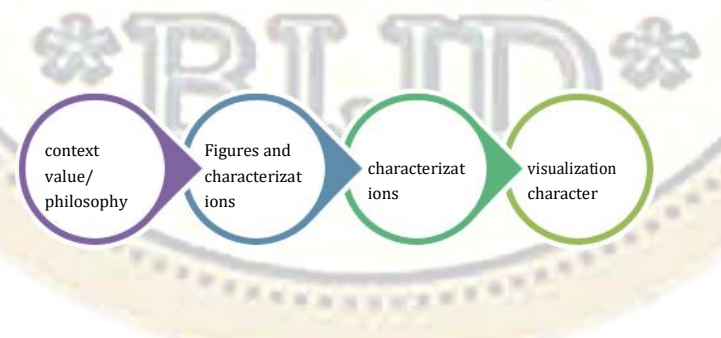

Figure 3. Characterization Patterns

(Source: Darisman, 2018)

The paradoxical characterizations are the initial analysis in character design or character design. Each character has a different context and role where the relationship presents to bridge the character context based on the values and philosophy of the background in story so that aspects of character visualization can be fulfilled and clearly formed. 


\section{CONCLUSION}

Characterizations reconstruct the characters and characterizations. Characterization produces forms of knowledge, both of them become one paradoxical bond relationship. The tendency of opposition presents in the narrative of the story. It can be seen that Kings and Knights in the context of his deity, Léngsér in the context of his humanity and deity, Dewa in the context of his humanity, the giants in the context of his humanity.

Knowledges is the basis or dimension of rational thinking in determining ideas and ideas for character formation. Each character has a rational dimension in accordance with the characterization capacity and course of the story. These dimensions include psychological dimensions, social and cultural dimensions, theological / teaching dimensions, and spiritual dimensions. The dimensions of this dimension can be described in detail so that personal characterization is complete. Basically character design or character design is the final process of character characterization. He is "present and there" through a search, dialectics and creativity through a resume that comes first as an idea or idea. Not only characters or characters exist without deepening the meaning of the experience of the story that shaped it. He presents from existence and manifest. Sundanese Pantun story is only one vehicle or medium of the many local wisdoms in the archipelago. For Sundanese people, the cultural results are very minimal with visuals, moreover the artifacts found do not provide significant results, the community only knows based on speech stories and notes or journals from other nations. Paradox or Paradosksial aesthetics can be developed as a method to explore stories or their characters in depth and comprehensively.

\section{BIBLIOGRAPHY}

1) Creswell, John W. 2012. Research Design. Pendekatan Kualitatif, Kuantitatif dan Mixed. Yogyakarta :Pustaka Pelajar.

2) Nurgiyantoro, Burhan.2012.Teori Pengkajian Fiksi. Yogyakarta: Gadjah Mada University Press.

3) Minderop, Albertine.2013. Metode Karakterisasi Telaah Fiksi. Jakarta: Yayasan Pustaka Obor Indonesia

4) Sumardjo, Jakob.2009.Simbol-Simbol Artefak Budaya Sunda. Bandung: Kelir

5) Sumardjo, Jakob.2010. Estetika Paradoks. Bandung: Sunan Ambu Press

6) Sumardjo, Jakob.2011.Sunda Pola Rasionalitas Budaya. Bandung : Kelir 
